\title{
Mobility in the Internationalisation of Higher Education Institutions
}

\author{
Sandro Serpa ${ }^{1}$, Suzana Nunes Caldeira ${ }^{2}$, Margarida S. Damião Serpa ${ }^{2}$, Rolando Lalanda Gonçalves ${ }^{2}$, Helena Mateus \\ Montenegro $^{3} \&$ Isabel Estrela Rego ${ }^{4}$ \\ 1 University of the Azores; Interdisciplinary Centre of Social Sciences - CICS.UAc/CICS.NOVA.UAc; \\ Interdisciplinary Centre for Childhood and Adolescence - NICA - UAc \\ ${ }^{2}$ University of the Azores, Interdisciplinary Centre of Social Sciences - CICS.UAc/CICS.NOVA.UAc \\ ${ }^{3}$ University of the Azores, Center of Humanistic Studies - CEHu \\ ${ }^{4}$ Research Institute of Volcanology and Risk Assessment - IVAR \\ Correspondence: Sandro Serpa, University of the Azores, Faculty of Social and Human Sciences, Department of \\ Sociology. Rua da Mãe de Deus, 9500-321 Ponta Delgada, the Azores, Portugal.
}

Received: March 13, 2020

Accepted: May 13, 2020

Online Published: May 14, 2020

doi:10.5430/ijhe.v9n4p46

URL: https://doi.org/10.5430/ijhe.v9n4p46

\section{Funding:}

University of Azores, Interdisciplinary Centre of Social Sciences - CICS.UAc/CICS.NOVA.UAc, UID/SOC/04647/2019, with the financial support of FCT/MEC through national funds and when applicable co-financing from the FEDER under the PT2020 Partnership Agreement.

\begin{abstract}
International mobility of higher education institutions' members within the European Union is explicitly encouraged and used as one of the higher education institutions' quality criteria. This paper aims to contribute to the analysis of the phenomenon of international mobility between higher education institutions, especially within the European area in the broad sense, and for which the ERASMUS+ Programme is paradigmatic. The authors have been linked to mobility processes by addressing issues of internationalisation and receiving and sending students and teachers in and out of their institution, and/or hosting them in curricular units taught by them or in other training actions. It is in this context that theoretical reflection has been carried out, to respond to the objective of analysing the relevance of mobility in the internationalisation of higher education institutions and to reflect on questions of its evaluation. It is concluded that there is interest in allowing a mutually enriching scientific dialogue for the personal and professional development of those involved - students, academics and other staff members. Furthermore, it is institutionally considered that the higher education institution is promoting its quality and image if it provides an in-depth exchange of ideas and practices that foster improvements in teaching and research of the institutions involved. It is also concluded that there is a need for structures to respond to this new reality and that the evaluation processes can contribute to measuring and promoting it.
\end{abstract}

Keywords: academic mobility, exchange, internationalisation of higher education, international student mobility, evaluating academic mobility

\section{Introduction}

Globalisation has brought along the internationalisation of teaching, achieved, for example, through partnerships, the hiring of teachers of different nationalities, the development of projects, teaching programmes, research and publications that result from articulation between different countries and academic mobility, covering the exchange of students, teachers, researchers and the remaining staff members (Pereira, Souza, Rodrigues, \& Dias, 2017; Carvalho, Backes, Lomba, \& Colomé, 2016; Weibl, 2015; Petzold \& Bucher, 2018; Binder, Schreier, Kühnen, \& Kedzior, 2013; Kompanets \& Väätänen, 2018; Perez-Encinas, Rodriguez-Pomeda, \& Josek, 2017; Oliveira \& Freitas, 2017; Beech, 2018; Kömíves, 2014; McAleer, Nakamura, \& Watkins, 2019; Bartha, Gubik, \& Rethi, 2019; Waters, 2018).

For example, Beech (2018) and Carvalho et al. (2016) draw attention to the existence of international student mobility as a migration industry with outgoing and incoming students. According to Carvalho et al (2016), "Through exchanges, students seek linguistic improvement, autonomy and demonstrate expectations regarding professional 
training. Moreover, this type of experience promotes great personal appreciation, as it provides students with a broader vision of the future" (p. 60).

Specifically in the European Union (EU), since the 1999 Bologna Declaration, calling for a common European educational identity (Pegalajar Palomino, Pérez Navío, \& Colmenero Ruiz, 2014), and with the Bologna process itself, an international higher education (HE) regime has been sought - and largely succeeded - in creating a direct equivalence between the various HE systems, through the European Credit Transfer System (ECTS) (Pereira et al., 2017). Furthermore, the Bologna process enabled greater academic collaboration and, possibly, the establishment of a system of international standards, facilitating the attainment of qualifications to meet the challenges of globalisation (Zahavi \& Friedman, 2019).

This internationalisation often takes place under intentionally created formal policy instruments, such as academic mobility programmes (Oliveira \& Freitas, 2017). In the EU, the ERASMUS programme, later called ERASMUS+, is exemplary in promoting academic mobility (Beerkens, Souto-Otero, de Wit, \& Huisman, 2015; Budraitis et al., 2019; Zahavi \& Friedman, 2019; Clemente-Ricolfe \& García-Pinto, 2019; Cairns, 2018; Dabasi-Halász et al., 2018; Fernández-Rovira, 2019; Idris, Ion, \& Seery, 2018; Perez-Encinas et al., 2017). Although there are other programmes, this one will be highlighted in this explanation. Other authors (Wilkins \& Neri, 2018; Wekullo, 2019) also deem it relevant and transversal.

The ERASMUS Programme emerged in 1987 and has had several versions. Currently, it is in the ERASMUS+ version (Fernández-Rovira, 2019; Enríquez, 2018; Kabanbayeva, Gureva, Bielik, \& Ostasz, 2019). The programme seeks to promote a common European awareness (Pereira et al., 2017; Dabasi-Halász et al., 2018) to support itelligent, sustainable and inclusive growth in the Europe 2020 strategy (Erasmus+, 2018, online) and to add to "contribute to internationalisation and excellence in education and training in the EU, driving creativity, innovation and a spirit of entrepreneurship, while promoting equality, social cohesion and active citizenship" (Erasmus+, 2018, online). It has contributed to the improvement in the quality of $\mathrm{HE}$ at the macro level of public policies (system policy), the institutional level and the individual level (Bryła, 2015), through, among other actions, a growing increase in academic mobility.

Given the increase in the number of participants, it is important to understand the reasons for the internationalisation dimension of education, which has varied over time, and sometimes with unintended consequences (Knight, 2013), the objectives pursued, how they were attained and the type of effects it caused. This helps to understand the extent to which mobility translates into potential impacts on the internationalisation of higher education institutions (HEIs), in areas such as mutual gains in terms of the acquisition of knowledge that would otherwise be difficult to achieve, both at the level of the learning or teaching area with the focus on mobility and of geographical aspects, historical and local lifestyles, the development of attitudes towards cultural diversity and contact or involvement with new educational and professional practices, or even the increased possibilities for subsequent employability or participation in research projects.

In summary, international mobility between members of HEIs in the EU is explicitly and politically promoted and used as one of HEIs' quality criteria. This role aims to contribute to the reflection on this phenomenon of international mobility between HEIs, especially in the European area, in a sideways direction, and for which the ERASMUS+ Programme is a paradigm.

To fulfil the objective of this work, specifically, analyse the relevance of mobility in the internationalisation of HEIs and define a proposal for a framework to assess the mobility dimension in HE, in several impacts through a literature review, the method described in the next section was adopted.

\section{Method}

The collection of information took place through a bibliographic survey that was carried out from June 6 to 15, 2019, by consulting the Online Knowledge Library (B-ON), which is well known and used in Portugal in the scientific environment. It "provides unlimited and permanent access to research and HEIs to the full texts of thousands of scientific journals and online ebooks from some of the most important content providers, through nationally negotiated subscriptions" (B-ON, n.d.). The search used the expressions "international mobility" in the title and, simultaneously, "higher education" in the abstract of research works. From all the information collected, essentially in the form of articles, books and reports, a selection was made by reading the respective abstracts. This selection was based on the research pieces' relevance to addressing the issue of mobility in the context of HEIs' internationalisation. At a later stage, the reading of the selected literature was deepened. 


\section{Internationalisation of Higher Education}

The European Commission intends to create a common HE framework in the different countries. This framework gives rise to a system of international command and coordination, in the scenario of promoting a European identity, making compatible the interests of the different parties involved (Zahavi \& Friedman, 2019; Bryla, 2015; Bartha et al., 2019).

However, the focus of the purposes of internationalisation has not always been the same. There is a profound change in the meaning of internationalisation of HE. According to Knight (2013),

Internationalisation of higher education was originally conceived in terms of exchange and sharing of ideas, cultures, knowledge, and values. Formalised academic relations between countries were normally expressed in bilateral cultural and scientific agreements. Today, the agreements often must take trade, economic, and political factors into account, representing a significant shift from the original idea of academic exchange (p. $88)$.

Guerreiro (2015) summarises the different reasons for the internationalisation of HEIs, as depicted in Table 1.

Table 1. Reasons for the internationalisation of HEIs

\begin{tabular}{ll}
\hline \multicolumn{1}{c}{ Group/reason } & \multicolumn{1}{c}{ Assumptions } \\
\hline 1st group & $\bullet$ national security \\
Political reasons & $\bullet$ peace promotion \\
& $\bullet$ mutual understanding among nations \\
& $\bullet$ national and regional identity formation \\
\hline 2nd group & $\bullet$ economic growth \\
Economic reasons & $\bullet$ increased competition \\
& $\bullet$ labour market response \\
& $\bullet$ financial incentives \\
3rd group & $\bullet$ development of citizenship \\
Socio-cultural reasons & $\bullet$ community development \\
& $\bullet$ promotion of intercultural understanding \\
Market reasons & $\bullet$ national cultural identity \\
\hline Academic reasons & $\bullet$ international dimension in education and research \\
& $\bullet$ academic quality improvement \\
\hline & $\bullet$ international renown and reputation of the HEI \\
\hline &
\end{tabular}

Source: Guerreiro, 2015, p. 9.

The reasons for internationalisation are, then, linked to various motivations, from the macro to the micro. In terms of macro motivations, it is mainly an issue of defending values that should be shared by the community at large, such as the understanding and coexistence of diverse cultures, following the ideas of creating internationalisation, economic competitiveness or brain attraction (brain-gain as opposed to brain-drain) (Knight, 2008, 2013; Miura, 2006; Payumo, Lan, \& Arasu, 2017; Al-Agtash \& Khadra, 2019). The qualification of people and the improvement of HEIs (Knight, 2008; Miura, 2006) regard micro type motivations, more directly linked to personal and institutional interests. Any of these reasons may be driven by political motivations (Rodríguez-Izquierdo, 2018).

Nevertheless, the internationalisation process is very complex (Knight, 2013) and encompasses several dimensions (Perez-Encinas et al., 2017; Waters, 2018; Knight, 2008; Du Toit, 2018). The elucidative graphical exposition of Al-Agtash and Khadra (2019) allows clarifying the dimensions of this complexity (Figure 1). 


\begin{tabular}{|c|c|c|}
\hline \multicolumn{3}{|c|}{ Institutional policy embedding internationalization as a strategic priority } \\
\hline - Leadership policy & - Intermational office & - Institutional partnership \\
\hline $\begin{array}{c}\text { Teaching } \\
\text { International relevance } \\
\text { Intercultural multilingual skills }\end{array}$ & $\begin{array}{l}\text { Research } \\
\text { Research of global significance } \\
\text { Publication of international value }\end{array}$ & $\begin{array}{l}\text { Community } \\
\text { International engagement } \\
\text { Professional development }\end{array}$ \\
\hline $\begin{array}{l}\text { Measurable elements } \\
\text { - Curricula structure } \\
\text { - Faculty with international } \\
\text { experience } \\
\text { - Student mix } \\
\text { - Study abroad and mobility } \\
\text { - Cultural and multi-lingual } \\
\text { integration } \\
\text { - Flying faculty co-teaching }\end{array}$ & $\begin{array}{l}\text { Measurable elements } \\
\text { - Joint research projects with } \\
\text { international peers } \\
\text { - External research funding } \\
\text { - Faculty with international } \\
\text { industrial experience } \\
\text { - Research visits and staff exchange } \\
\text { - SI indexed publications }\end{array}$ & $\begin{array}{l}\text { Measurable elements } \\
\text { - Community development } \\
\text { projects } \\
\text { - Continuing education } \\
\text { programs } \\
\text { - Professional qualification } \\
\text { programs } \\
\text { - International twining activities }\end{array}$ \\
\hline \multicolumn{3}{|c|}{ Performance, outcomes, and long-term impact } \\
\hline - Employability of graduates & - Institutional ranking & - National standing \\
\hline
\end{tabular}

Source: Al-Agtash and Khadra, 2019, p. 73.

Figure 1. Internationalisation framework

The analysis of this figure leads to the conclusion that, for the prioritisation of internationalisation in the HEI, it is important to ensure leadership policies, the existence of international offices and institutional partnerships that, through dimensions such as teaching, research and community engagement, allow to achieve better performances and results with long-term effects on employability, institutional ranking and the country's position in respect of others. In this figure, some of the aspects or indicators of the dimensions considered are also explained, which is certainly useful for the evaluation of internationalisation.

\section{Assessment Aspects of Internationalisation}

The assessment of internationalisation entails different dimensions, as will be seen below, which clarify the scope and focus of descriptive and evaluative studies in the area. A superficial consideration of them, or only of some of them, may lead to less consistent or partial results, easily motivating the construction of beliefs or myths about the mere goodness of internationalisation in HE.

\subsection{Dimensions of the Assessment of Internationalisation}

Al-Agtash and Khadra (2019) sustain that there are four major dimensions to be considered, in general, in the assessment of the internationalisation of a HEI: institutional, teaching, research, and community engagement, but being able to be flexible according to the objectives of internationalisation of each institution per se. According to the authors, the institutional dimension points toward the need to consider the vision, mission and goals of the organisation, the partnerships with external entities, the structure of the international relationships office, the way it coordinates activities with foreign HEIs and how the values of cultural integration (multilingual performance, tolerance, etc.) translate into the main processes of the institution. The teaching dimension encompasses the assessment of (i) the development of curricula, including learning with international importance, especially language and multiculturalism; (ii) the selection processes of international students, their diversity and proportion; (iii) the procedures and effectiveness of the international relationships office; (iv) the international experience of teachers or the involvement of foreign teachers in teaching; and (v) the operation of the teaching activities developed. As for the dimension of research, it entails (i) the analysis of the research conducted by the faculty; (ii) the involvement of the faculty in international and internationally funded projects; (iii) the selection of international faculty and their international research; (iv) the institutional support for international faculty mobility; (v) the number of indexed publications and the number of international citations; and (vi) research training, including the involvement of students in research projects. Finally, the dimension of community engagement has to do with (i) the implementation 
of projects aimed at the development of the community and society in general; (ii) the existence of lifelong training centres, with courses of international importance; (iii) partnerships with technology companies that ensure proper professional qualification; and (iv) the involvement in activities that enable communities to develop a better cultural understanding and access to information and knowledge resources.

In this framework, not only international student mobility (Bryła, 2015; Caruana, 2014; Kabanbayeva et al., 2019; Kömíves, 2014) but also the academic and the administrative staff play a central role in the competition between HEIs, with deep influences on the institution's world ranking position and the recognition of academics (Knight, 2013; McAleer et al., 2019; Petzold \& Bucher, 2018), inasmuch that "It's impossible to increase the quality level of the higher education without the intensification of the universities' staff mobility rate" (Kömíves, 2014, p. 1189). Today, we are witnessing a scenario of the need for mobility and not just its possibility (Petzold \& Bucher, 2018). To some extent, there is a strengthening of what was stated in 2015 by Beech: "international students come to accept mobility as a taken for granted" (p. 332). There is an awareness that from the moment mobility becomes a criterion for evaluating HEIs and the training that they provide, the need for mobility becomes a defining element of quality or, ultimately, of the survival of a given training.

Before going deeper into aspects of mobility, some of the myths of internationalisation are presented, to warn of simplistic perspectives of it and even of the difficulty in determining its benefits.

\subsection{Myths of Internationalisation}

The myths of internationalisation are usually associated with the idea that the number of accreditations, partnerships, mobilities, activities and intercultural exchanges are sufficient to define their meaning and guiding principles, transforming internationalisation into a synonym of international actions, without questioning the extent to which these actions embody a process that adds to democratise knowledge, minimise inequalities and deepen the functions, objectives and effectiveness of the training provided by HEIs.

In Table 2, Carla Guerreiro (2015) recovers her reading of the myths of HE internationalisation put forth by Jane Knight in 2011, highlighting, in the last column, her misconceptions. 
Table 2. The myths of higher education internationalisation

\begin{tabular}{|c|c|c|}
\hline Myth & Rationale & Error \\
\hline $\begin{array}{l}\text { Myth } 1 \\
\text { Foreign students as } \\
\text { agents of } \\
\text { internationalisation }\end{array}$ & $\begin{array}{l}\text { a) foreign students } \\
\text { produce a more } \\
\text { internationalised culture and } \\
\text { institutional curriculum; } \\
\text { b) The main reason to recruit } \\
\text { foreign students is to help } \\
\text { internationalise the institution. }\end{array}$ & $\begin{array}{l}\text { Foreign students are also associated with } \\
\text { other motivations, such as income } \\
\text { generation or the desire for better positions } \\
\text { in international rankings. }\end{array}$ \\
\hline $\begin{array}{l}\text { Myth } 2 \\
\text { The international } \\
\text { reputation as a } \\
\text { representative of } \\
\text { quality }\end{array}$ & $\begin{array}{l}\text { The more international an } \\
\text { institution is - in terms of } \\
\text { students, teachers, curriculum, } \\
\text { research and agreements - the } \\
\text { better its reputation is. }\end{array}$ & $\begin{array}{l}\text { a) Internationalisation does not always } \\
\text { translate into quality improvement; } \\
\text { b) For example, cases of questionable } \\
\text { admission and highly dependent exit } \\
\text { patterns in revenues. }\end{array}$ \\
\hline $\begin{array}{l}\text { Myth } 3 \\
\text { International } \\
\text { institutional } \\
\text { arrangements }\end{array}$ & $\begin{array}{l}\text { The more international } \\
\text { agreements or partnerships a } \\
\text { HEI has, the more prestigious } \\
\text { and attractive it is to other } \\
\text { institutions and students. }\end{array}$ & $\begin{array}{l}\text { a) Quantity is seen as more important than } \\
\text { quality, resulting in the use of the list of } \\
\text { international agreements as a symbol of } \\
\text { status rather than effective academic } \\
\text { collaborations; } \\
\text { b) Practice shows that most institutions are } \\
\text { unable to manage or benefit from many } \\
\text { agreements. }\end{array}$ \\
\hline $\begin{array}{l}\text { Myth } 4 \\
\text { International } \\
\text { accreditation }\end{array}$ & $\begin{array}{l}\text { The higher the number of } \\
\text { international accreditations (by } \\
\text { international agencies) the } \\
\text { higher the level of } \\
\text { internationalisation of a HEI } \\
\text { and the better the positioning of } \\
\text { the HEI before the academic } \\
\text { universe. }\end{array}$ & $\begin{array}{l}\text { Quality foreign recognition is not enough } \\
\text { because it is not enough to meet an endless } \\
\text { number of requirements, assessed at a given } \\
\text { time. } \\
\text { It is necessary to monitor the scope, scale } \\
\text { and international value of the outcome of the } \\
\text { teaching/learning process, research and } \\
\text { community services. }\end{array}$ \\
\hline $\begin{array}{l}\text { Myth } 5 \\
\text { Global branding }\end{array}$ & $\begin{array}{l}\text { The goal of a HEIs' } \\
\text { internationalisation efforts is to } \\
\text { improve the global brand or } \\
\text { positioning. }\end{array}$ & $\begin{array}{l}\text { An international marketing strategy is not an } \\
\text { internationalisation plan. }\end{array}$ \\
\hline
\end{tabular}

Source: Guerreiro, 2015, p. 21, adapted from Knight, 2011.

Other myths are pointed out in the literature regarding the idea that HE is, by itself, international in nature, or that the evaluation of intercultural competences is dispensable because they are naturally acquired in actions of internationalisation, as documented by De Wit (2015).

The presentation by Brandenburg and Federkeil (2007) of indicators to measure internationalisation is an example of the valuation of internationalisation as a quantification of a set of activities of an international nature or content. The number of foreign teachers, visiting researchers, incoming students, outgoing students, students participating in classes abroad and foreign graduates, among others, in proportion to the respective totals, are mentioned. It is a collection of information based on objective and easily comparable indicators between different HEIs, but they do not express or exhaust the complexity of the internationalisation processes.

The allusion to these myths alerts to possible reductionist visions of internationalisation and adds to better identification of its critical aspects, as well as to a deeper understanding of theoretical discussions about it, bearing in mind that it cannot be dissociated from the HEIs' contexts, local issues and mission.

Mobility in the academic environment, particularly that of students, will be further developed in section 5, given its weight in the internationalisation processes. 


\section{Results and Evaluation Processes of International Mobility}

As mentioned, international academic mobility is a relevant component of internationalisation (Bryła, 2015), and it is important to understand the dimensions it can cover.

For Knight (2013), internationalisation, more specifically, "cross-border education", involves the following types of academic mobility: "(1) people-faculty, students, scholars; (2) programmes - twinning, franchise, double/joint; (3) providers - branch campus, virtual; (4) projects - research, benchmarking, curriculum; and (5) policies - credits, quality assurance" (Knight, 2013, p. 85), with credits being an essential element for their implementation (Knight, 2013; Kőmíves, 2014).

Of the dimensions listed, particular attention will be ascribed to the evaluation of student mobility.

\subsection{Analysis of the Variables Linked to the Performance of Students in Mobility}

Not all the experience of international student mobility is positive. The advantages attained through it depend on the individual context of the experience, which is complex to manage by the institutions (Dziewanowska, Quan, \& Pearce, 2019). It cannot be stated that they depend only on students' previous performance, because each mobility process is associated with challenges and dynamics that go beyond usual forms of operation. However, some basic conditions and skills facilitate the management of these new challenges and dynamics, such as motivation and mastery of the English language (Guerreiro, 2015), and it is particularly complex in situations of students with disabilities (Du Toit, 2018). In terms of motivations, e.g. of Erasmus students, they are diverse and can be concurrent or not, as indicated in the extensive literature review by Clemente-Ricolfe and García-Pinto (2019): learning a language, seeking new experiences/personal development, professional development, cultural attractiveness of the destination, leisure, personal recommendations (family, friends, etc.), economic level of the host country/affordable price, geographical proximity, experiencing a new education system, improving the academic record, prestige/academic quality of the host institution, range of subjects for study, admission/access requirements, weather, improving the CV. Enhancing English performance could also be a motivation.

The process of acculturation or sociocultural adaptation takes place in a cultural exchange based on dimensions such as the individual, the culture of the receiving organisation and the national societal culture, which may not be easy for the individual (Carvalho et al., 2016; Caruana, 2014; Kompanets \& Väätänen, 2019; Serpa, 2016; Carvalho et al., 2016; Tran \& Vu, 2017; Rodríguez-Izquierdo, 2018; Oliveira \& Freitas, 2017; Perez-Encinas et al., 2017; Guerreiro, 2015; Ma \& Wen, 2018; Chen \& Chen, 2018; Beerkens et al., 2015; Wekullo, 2019; Ribeiro, 2014). Figure 2 clarifies, in some way, the variables linked to these dimensions and highlights some of the relationships between them, stressing the fact that the adaptation of the mobile student cannot ignore the effect of the variables at stake. 


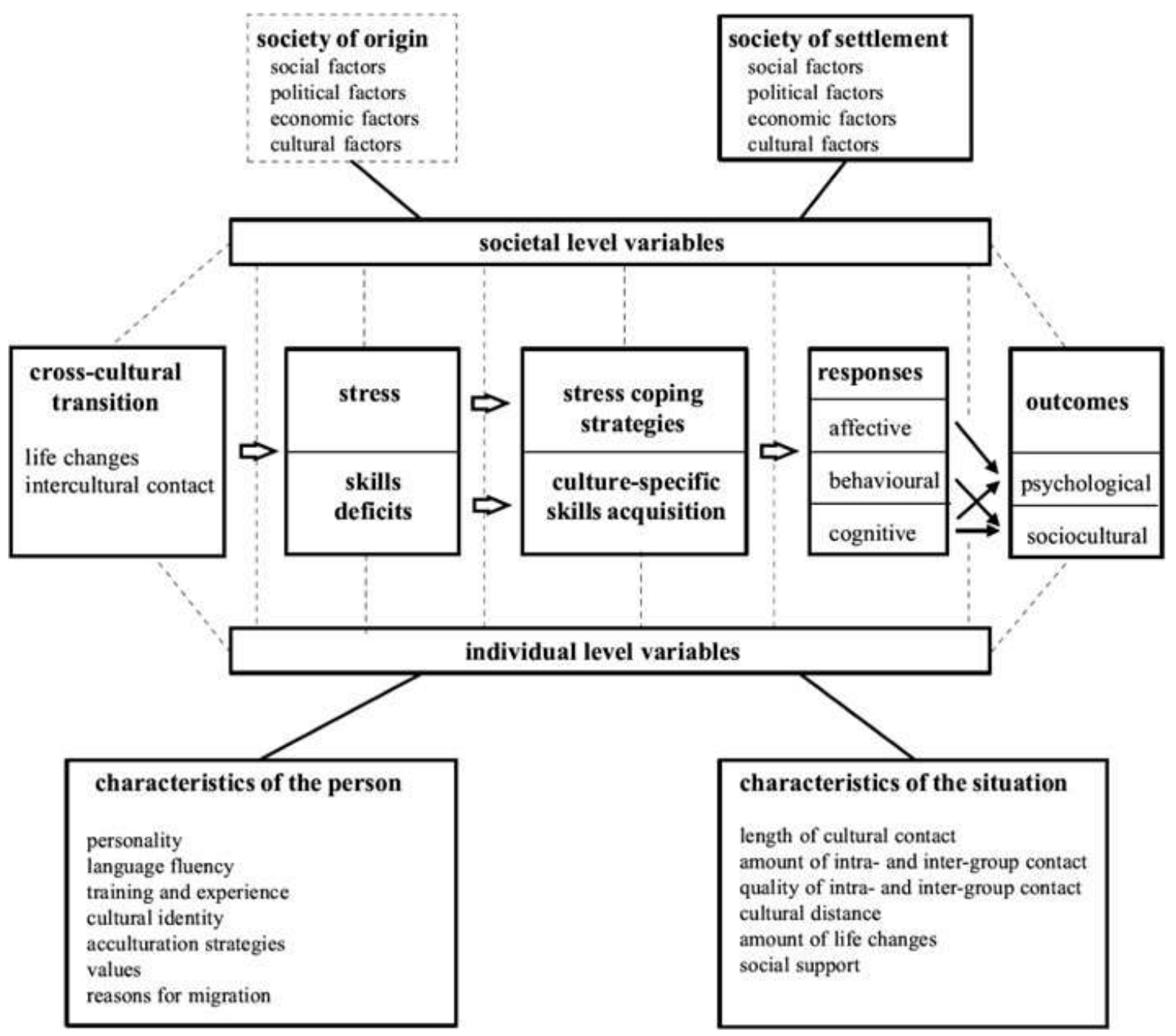

Source: Zhou, Jindal-Snape, Topping, \& Todman 2008, p. 69, adapted from Ward, Bochner \& Furnham, 2001.

Figure 2. The acculturation process

From the data of this figure, Zhou et al. (2008) alert to two forms of interaction that students can have with the culture of the destination country, namely one focused on the knowledge of region's geography, history, institutions and cultural artefacts (literature, film, fine arts, etc.), and another focused on the local inhabitants' sociological knowledge, avoiding to confine to the bubble of contacts that Erasmus students usually create among themselves.

When the student does not know anyone in the destination country, he or she is impelled to create new friendships, but these will be easier to build with other international students than with local ones, given the differences in lifestyle, which is more pronounced if a short stay is foreseen (Ribeiro, 2014).

Social networks of friendship and kinship can be a crucial element for better adaptation (Beech, 2015). According to Idris et al. (2018), the social isolation of international students can have negative consequences on their academic performance and can be avoided, for Bartha et al. (2019), if the HEI services provide the necessary support in advance, for example, in terms of language proficiency, adjustment of credits to the subjects and skills to be developed, and attendance of international summer courses.

It should be noted that the adaptation process occurs throughout the different stages of mobility, i.e. before the mobility (provision of information and preparation of students), upon arrival at the destination institution (conditions and services facilitating immediate adaptation), during the remaining period of study (support for integration into the community) and after return to the home institution (reintegration into the home community) (Perez-Encinas et al., 2017). 


\subsection{Results of International Academic Mobility}

Although the results of international mobility may have both a very positive reading and point to some weaknesses (Knight, 2013: Caruana, 2014; Carvalho et al., 2016; Kabanbayeva et al., 2019; Bryla, 2015; Budraitis et al., 2019; Fernández-Rovira, 2019; Popa \& Knezevic, 2018), most studies on the effects of international mobility of academic staff deem it positive (Groves, López, \& Carvalho, 2018). Rodríguez-Izquierdo (2018), for example, highlights the improvement of intercultural sensitivity, and Wekullo (2019) emphasises diverse potentials: (a) facilitating regular professional development training for faculty, staff, and students to communicate regarding the significance of creating an inclusive learning environment for all (b) creating awareness of the university support services available to international students and their usefulness (c) formalizing peer support learning and mentoring for international students; and (d) providing a broad range of content that includes multicultural elements for promoting student interactions (p. 332).

It follows that "engaging international students does not necessarily improve their experiences in foreign institutions; rather, there are multiple factors that need to be considered" (Wekullo, 2019, p. 332). It should be noted that mobility, while not sufficient, is essential as a crucial dimension of the internationalisation of HEIs: "It is imperative that the international, intercultural and global dimensions of higher education continue to be proactive, responsive and innovative while keeping a close watch on unanticipated spin-offs, misconceptions and implications" (Knight, 2013, p. 89).

In Europe, concerning ERASMUS, Budraitis et al. (2019) conclude that it has had an impact on academic mobility and that it is still and increasingly the paradigm plan for the European Commission to promote it. Other authors acknowledge that the Programme will be intrinsically linked to HE quality improvement, as well as to its evaluation and financing (Kömíves, 2014; Bartha et al., 2019).

On the one hand, Kabanbayeva et al. (2019) state that

It appears that the benefits of an academic experience abroad could be expressed in a form of seven key criteria: (i) on the personal level the participants of the student exchange programs can improve their employability, (ii) academic exchange programs serve as a platform for learning new and improving current foreign language skills, (iii) the participants of academic exchange programs improve their self-sufficiency, (iv) and train intercultural skills; further, (v) academic exchange programs enable universities to exchange best practise, (vi) academic exchange programs allow to compare results and identify their strengths and weaknesses, (vii) academic exchange programs make the learning process more transparent (p. 334).

On the other hand, Budraitis et al. (2019) express the variety of contributions of the Programme Erasmus+ Higher Education Strategic Partnerships and Knowledge Alliances (Table 3).

Table 3. Contributions of the Erasmus+ programme to the improvement and relevance of $\mathrm{HE}$

$$
\text { Outcomes of HE Strategic Partnerships }
$$

1. HE Strategic Partnerships (SPs) already contributed and will contribute in the future to improved quality of higher education through redesign of curricula, programmes and modules in HEIs driven by better Information and Communication Technologies (ICT) integration

2. Labour markets in Programme Countries should see an influx of graduates with improved digital competences, some of them direct beneficiaries of (mobility) activities in HE SPs, while others - students benefiting from the ICT-based or ICT-enriched intellectual outputs developed as a result of HE SPs.

3. HE SPs directly contributed to opening up of higher education as they made all their intellectual outputs developed in the course of the project accessible online to virtually anyone. This obligatory practical application of ICT enabled more active knowledge exchange and should be useful for cross-institutional learning, new cooperation opportunities, etc.

4. As the university teaching staff got involved in project activities and/or directly contributed to the development of ICT-based and otherwise ICT-featuring intellectual outputs, HE SPs end up contributing to the improvement of the workforce in higher education, capable of ICT application for teaching purposes and delivery of innovative ICT-enhanced curriculum.

5. Relevance of higher education should continue improving as a result of its improved accessibility to students from disadvantaged socioeconomic backgrounds and young people belonging to marginalised groups.

Source: Adapted from Budraitis et al. (2019). 
These data connect with Bryla's perspective (2015), when the author ascertains the increase in employability and the idea that "Erasmus mobility contributes to the acquisition of multiple skills and competencies, which are highly valued by future employers, but also constitutes a valuable social and cultural experience" (p. 640). Also on the results of the Erasmus Programme, in its different versions, in a literature review by Kabanbayeva et al. (2019), it can be seen that the permanence of months in a country can create an appetite for a certain product, impelling, in the future, the search for it.

However, as mentioned, not everything is positive as regards international academic mobility. On the one hand, Caruana et al. (2014) warn that "[...] there is little evidence to suggest the benefits of international mobility for intercultural understanding, which is an essential quality of the global citizen" (p. 85). On the other hand, authors such as Bartha et al. (2019), Cairns (2019), Kabanbayeva et al. (2019), Guerreiro (2015), Oliveira and Freitas (2017), Petzold and Bucher (2018), França, Alves, and Padilla (2018), Borges and Afonso (2018), Iorio and Pereira (2018), and Courtois (2018) argue that international mobility can even, as will be seen ahead, foster inequalities. While it is true that students' social networks are an important element in their decision-making and recruitment to undertake a mobility process (Beech, 2015), this raises the issue that "those not from elite and middleclass backgrounds will have fewer opportunities to take part in these networks; thus, there is a tendency for social networks to replicate privilege" (Beech, 2015, p. 347).

Another alert comes from Dziewanowska et al. (2019). The authors sustain that

The assumption that all international experience is positive is false. Indeed, the nature and extent of value creation through international mobility is very largely down to the individual and particular context of the experience. This makes it less 'manageable' by organisations and more reliant upon the selection of individuals, with previous performance clearly indicative of the future. The results of this study highlight the importance and influence of a reflection after returning 'home' - which could be facilitated - and the openness to failure and learning in both the individual and the organisation" (Dziewanowska et al., 2019, p. 59).

Borges and Afonso (2018) also warn about the current hegemony of the English language, as it is the lingua franca and the academic language of international student mobility. The authors comment that "English continues to consolidate itself as the lingua franca of production and dissemination of technical and scientific knowledge, in different areas, also functioning, and increasingly, as a tool for building new subjectivities and new cognitive ways of perceiving and interpreting the world" (Borges \& Afonso, 2018, p. 61). Moreover, Borges and Afonso (2018) contend that international mobility shows many imbalances. Even among countries with semi-peripheral positions in the world context, the two directions of the same mobility route are quite asymmetric (Pereira et al., 2017; Dabasi-Halász et al., 2018; Courtois, 2018).

The culture of international mobility in HE (Beech, 2015) must be built in an inclusive sense, fostering equity in the international mobility process (Bryla, 2015). This action will result, or not, in better fruits for the recognition of interculturality as a factor for the improvement of relationships between communities and States. Relationships with the host academic community and local communities allow mobile students to interact in a very close way, distinct from visual and sound images they may have from a distance. This proximity, per se, cannot fail to be inclusive, adding to the establishment of ties that, in the future, will contribute to the recognition of the other. It is something that, paraphrasing Wekullo (2019), "takes time, and international students require significant support from their host institutions" (p. 332).

\subsection{Assessment and Improvement Procedures for International Mobility}

In mobility assessment procedures, it is important to take into account some of the components of any assessment process, such as the basic functions, the perspectives or evaluation logic, the dimensions under assessment and the criteria to assess them, regardless of whether the collections are more open or pre-established (sometimes based on the use of indicators).

As a first step in the evaluation processes of mobility in HE, it is important to clarify the functions it is intended for and how its results are expected to be used. Depending on the framework given by these functions, the evaluation process may take on different perspectives or strategies. For example, if practical improvements are to be made, the strategy of involving stakeholders throughout the evaluation process is a priority. In this situation, the evaluation is used, during the process, for those involved to monitor the action itself, from the clarification and negotiation of needs, requirements and interests, either of the institution or individual or subgroups. Thus, it is not the same thing to want to know the evaluators' point of view on mobility and to want to involve those evaluated in improving it, or, on 
the other hand, to want to identify the perceptions of impact and to determine the transfer of learning to contexts other than training, or the impact of mobility in institutional or systemic terms, in the wake of the assessment proposals of Kirkpatrick and Kirkpatrick (2006) or Tamkin, Yarnall, and Kerrin (2002). While some of these procedures approach the investigative processes, others require decisions on what to do with the results in the contexts evaluated.

Some of the dimensions to be considered in a mobility evaluation have been mentioned throughout this work. To make it convenient to determine or simply understand, it is also necessary to consider the cultural position of the various stakeholders, especially those directly involved as interested participants (Tran \& Vu, 2017; Nilemar \& Brown, 2019; Almansour, 2015; Tran \& Vu, 2017; Arkoudis, Dollinger, Baik, \& Patience, 2018; Clemente-Ricolfe \& García-Pinto, 2019). In the case of students,

Their engagement varied depending on the student's background, major, region, and type of institution. These students faced unique and uneven experiences with social support, academics, community identity, connectedness, and perceived discrimination (Wekullo, 2019, p. 320).

However, Bryla (2015, p. 634) warns that "potentially better" students are likely to be those with the greatest mobility, which may explain part of the gains from such mobility, if one considers, for example, the remuneration of the profession subsequently performed. This is another variable to be considered when measuring the effects of mobility.

Wekullo (2019) suggests that students have several ways to improve their academic mobility:

They need to be proactive, seek more intense academic challenges, plan meaningful interactions with faculty, staff, and other students, improve their connectedness by engaging in serious conversations with students from other races, regions, and personal backgrounds, participate in practical and field experiences, and get more involved in the learning community and community service to improve their overall academic experience (p. 333).

Moreover, the continuous evaluation of mobility programs, both at the systemic, institutional and individual levels, is essential for their improvement and increasing effectiveness and efficiency (Bartha et al., 2019), improving the quality of service that HEIs provide (Almansour, 2015; Perez-Encinas et al., 2017; Oliveira \& Freitas, 2017; Binder et al., 2013).

A recent study by Budraitis et al. (2019) makes several recommendations for the improvement of academic mobility (Table 4).

Table 4. Recommendations for improving academic mobility

Recommendations

1. Take active measures to facilitate policy learning and exploitation of outcomes produced by Higher Education Strategic Partnerships and Knowledge Alliances at the systemic level.

2. Support more actively cross-project and cross-action learning.

3. Make additional efforts in both Higher Education Strategic Partnerships and Knowledge Alliances to secure higher commitment to embedding project outputs within participating organisations and ensure organisation-wide awareness of these outputs.

4. Retain the defining features of both Higher Education Strategic Partnerships and Knowledge Alliances, allowing the future projects to build on the complementarities and strengths of these features.

5. Take into consideration the success factors of a successful transnational cooperation project in future Strategic Partnerships in Higher Education and Knowledge Alliances.

6. Take measures to address the increasing demand for more active monitoring of the Erasmus+ transnational cooperation in the higher education project portfolio.

Source: Budraitis et al., 2019.

It can thus be concluded that mobility, if successful, provides a stimulating exchange of HE quality and increases the level of knowledge of those involved, both culturally, academically and professionally. Mobility participants are expected to become more demanding and critical with themselves and with others, but also more willing to respect cultural differences (Bryla, 2015; Perez-Encinas et al., 2017; Oliveira \& Freitas, 2017; Wilkins \& Neri, 2019), from a 
"responsibility in mobility" perspective (Tran \& Vu, 2017):

interpersonal responsibility refers to international students' perceived responsibilities for maintaining a respectful and considerate attitude to other members participating in their learning space, harmonising with other students, being honest to their teachers, and helping other international peers whenever possible $[\ldots]$ In order to achieve this, it is important for host institutions to ensure the productive conditions and external opportunities for international students to exercise responsibility as intercultural members and learners (Tran \& Vu, 2017, pp. 572-573).

\section{Conclusions and Recommendations}

In the framework of $\mathrm{HE}$, the need to be acquainted with the various dimensions and variables of mobility and internationalisation processes (Perez-Encinas et al., 2017; Waters, 2018; Knight, 2008; Du Toit, 2018; Al-Agtash \& Khadra, 2019) led us to consider the need to contribute to an evaluation model that will hopefully improve the dynamics already established and increase the effectiveness of the individual exchanges and institutional partnerships that are developed within the scope of international mobility projects and programmes.

Within this framework, there is an urgent need for a correct assessment of student mobility by introducing practical improvements through the involvement of stakeholders throughout the assessment process. From this perspective, the evaluation of mobility programmes should be made at the systemic, institutional and individual levels, aiming for their improvement and increasing effectiveness and efficiency (Bartha et al., 2019).

In the institutional sphere, it is important to ensure the existence of international offices and to foster institutional partnerships, which, both through teaching, research and community engagement, will improve results, with long-term effects on employability, institutional ranking and the relationship between the different countries involved.

The positive impacts on the organisational culture of institutions involved in processes of internationalisation and mobility come from several factors. Among these, we can highlight the interculturality experienced by the different actors in this process, which is expected to be inclusive and generate new socio-cultural and socio-economic dynamics. These, in turn, can foster new forms of interaction between these institutions and their relevant contexts, with positive impacts on employability, quality and the increase in the level of knowledge of those involved, both culturally, academically and professionally.

The need to consider not only the quantitative dimension (number of mobility processes) but also the qualitative dimension in an interactive perspective of the different actors is, therefore, highlighted.

In short, four ideas are presented:

The representations and practices of the academics themselves, and even more of the staff, are much less studied than those of the students in their process of international mobility, impact and gender, and it is necessary to deepen the knowledge of this audience.

In many of the studies consulted, the results presented derive from the collection of information that describes, from the respondents' point of view, expectations and events experienced, as well as perceptions of impact. The assessment of mobility may also include benchmarking between those who have experienced mobility and those who have not. In this case, it would be interesting to explore the gains obtained from training abroad and what corresponds to it in the country of origin.

It should be noted that it is not easy to find research on the organisational and social gains of mobility from the collection of factual data before, during and after it, i.e. to obtain benefits that would not be achieved without mobility. This is difficult to determine, but it can be a challenge to find credible procedures for monitoring the processes and results of mobility.

To improve the mobility system, an evaluation perspective is suggested that allows the results of the evaluation to be used by those involved in the process to monitor the action itself, based on the clarification of the needs and requirements of the various stakeholders.

\section{References}

Almansour, S. (2015). The challenges of international collaboration: Perspectives from Princess Nourah Bint Abdulrahman University. Cogent Education, 2(1), 1118201. https://doi.org/10.1080/2331186X.2015.111820

Al-Agtash, S., \& Khadra, L. (2019). Internationalization context of Arabia higher education. International Journal of Higher Education, 8(2), 68. https://doi.org/10.5430/ijhe.v8n2p68 
Arkoudis, S., Dollinger, M., Baik, C., \& Patience, A. (2018). International students' experience in Australian higher education: Can we do better? Higher Education, 77(5), 799-813. https://doi.org/10.1007/s10734-018-0302-x

B-ON (n.d.). About us. Retrieved September 19, 2019, from https://www.b-on.pt/quem-somos/

Bartha, Z., Gubik, A. S., \& Rethi, G. (2019). Management of innovations in Hungarian HEIs: Enhancing the Erasmus mobility programme. Marketing and Management of Innovations, 84-95. http://doi.org/10.21272/mmi.2019.1-07

Beech, S. E. (2015). International student mobility: The role of social networks. Social \& Cultural Geography, 16(3), 332-350. https://doi.org/10.1080/14649365.2014.983961

Beech, S. E. (2018). Adapting to change in the higher education system: International student mobility as a migration industry. Journal of Ethnic and Migration Studies, 44(4), 610-625. https://doi.org/10.1080/1369183X.2017.1315515

Beerkens, M., Souto-Otero, M., de Wit, H., \& Huisman, J. (2015). Similar students and different countries? An analysis of the barriers and drivers for Erasmus participation in seven countries. Journal of Studies in International Education, 20(2), 184-204. https://doi.org/10.1177/1028315315595703

Binder, N., Schreier, M., Kühnen, U., \& Kedzior, K. K. (2013). Integrating international students into tertiary education using intercultural peer-to-peer training at Jacobs University Bremen, Germany. Journal of Education and Training Studies, 1(2). https://doi.org/10.11114/jets.v1i2.170

Borges, R., \& Afonso, A. (2018). Why subaltern language? Yes, we speak Portuguese! Para uma crítica da colonialidade da língua na mobilidade estudantil internacional [Why subaltern language? Yes, we speak Portuguese! For a critique of the coloniality of language in international student mobility]. Communication and Society, 34(0), 59-72. http://dx.doi.org/10.17231/comsoc.34(2018).2935

Brandenburg, U., \& Federkeil, G. (2007). How to measure internationality and internationalisation of higher education institutions? Indicators and key figures. Gutersloh, Germany: Center for Higher Education Development.

Bryła, P. (2015). The impact of international student mobility on subsequent employment and professional career: A large-scale survey among Polish former Erasmus students. Procedia - Social and Behavioral Sciences, 176, 633-641. https://doi.org/10.1016/j.sbspro.2015.01.521

Budraitis, M., Nakrošis, V., Caturianas, D., Stankevičius, L., Martinaitis, G., Statulevičiūtè, G., Zinkevičiūtè, K., Dachs, B., Dinges, M., Kalcik, R., Köngeter, A., \& Wang, A. (2019). Study on the impact of Erasmus+ Higher Education Partnerships and Knowledge Alliances at local, national and European levels on key higher education policy priorities. Final report. Brussels: European Commission. Retrieved from http://sepie.es/doc/comunicacion/publicaciones/2019/study_on_the_impact_of_erasmus_HE_partnerships_and_ knowledge.pdf

Cairns, D. (2018). Researching social inclusion in student mobility: Methodological strategies in studying the Erasmus programme. International Journal of Research \& Method in Education, 42(2), 137-147. https://doi.org/10.1080/1743727X.2018.1446928

Caruana, V. (2014). Re-thinking global citizenship in higher education: From cosmopolitanism and international mobility to cosmopolitanisation, resilience and resilient thinking. Higher Education Quarterly, 68(1), 85-104. https://doi.org/10.1111/hequ.12030

Carvalho, J., Backes, D., Lomba, M., \& Colomé, J. (2016). International academic mobility: An education opportunity for future nurses. Revista de Enfermagem Referência, IV Série(10), 59-68. http://dx.doi.org/10.12707/RIV16018

Chen, L., \& Chen, T.-L. (2018). International students' conceptions of the sustainable internationalization of business education in Taiwan. Sustainability, 10(11), 4292. https://doi.org/10.3390/su10114292

Clemente-Ricolfe, J.-S., \& García-Pinto, P. (2019). Erasmus university students motivation and segments: The case of Universitat Politècnica de València, Spain. Journal of Educational and Social Research, 9(2), 72-82. https://doi.org/10.2478/jesr-2019-0015

Courtois, A. (2018). "It doesn't really matter which university you attend or which subject you study while abroad." The massification of student mobility programmes and its implications for equality in higher education. European Journal of Higher Education, 8(1), 99-114. https://doi.org/10.1080/21568235.2017.1373027 
Dabasi-Halász, Z., Kiss, J., Manafi, I., Marinescu, D. E., Lipták, K., Roman, M., \& Lorenzo-Rodriguez, J. (2018). International youth mobility in Eastern and Western Europe - The case of the Erasmus+ programme. Migration Letters, 16(1), 61-72. https://doi.org/10.33182/ml.v16i1.626

De Wit, H. (2015). Internationalization of higher education: Nine misconceptions. International Higher Education, 64, 1-6. https://doi.org/10.6017/ihe.2011.64.8556

Du Toit, N. (HG) (2018). Designing a model for facilitating the inclusion of higher education international students with disabilities in South Africa. Social Inclusion, 6(4), 168. http://dx.doi.org/10.17645/si.v6i4.1666

Dziewanowska, K., Quan, R., \& Pearce, A. (2019). Capturing the value of international staff mobility in higher education: A customer-dominant logic approach. Problemy Zarzadzania, 4(77), 43-62. http://dx.doi.org/10.7172/1644-9584.77.3

Enriquez, J. G. (2018). The importance of academic mobility: The Erasmus+ program. IT Professional, 20(5), 79-82. https://doi.org/10.1109/mitp.2018.053891341

Erasmus+ (2018, online). Objectives. Aims of the E+ Education and Training Programme. Retrieved from https://www.erasmusmais.pt/o-programa?lang=en

Fernández-Rovira, C. (2019). The journey into the European public sphere. The case of the Erasmus programme. Universitas, 30, 79-95. https://doi.org/10.17163/uni.n30.2019.04

França, T., Alves, E., \& Padilla, B. (2018). Portuguese policies fostering international student mobility: A colonial legacy or a new strategy? Globalisation, Societies and Education, 16(3), 325-338. https://doi.org/10.1080/14767724.2018.1457431

Groves, T., López, E. M., \& Carvalho, T. (2018). The impact of international mobility as experienced by Spanish academics. European Journal of Higher Education, 8(1), 83-98. https://doi.org/10.1080/21568235.2017.1388187

Guerreiro, C. (2015). The internationalisation of Portuguese higher education. The reasons, the strategies and the challenges. Unpublished master's dissertation. Porto: Polytechnic of Porto.

Idris, A., Ion, G., \& Seery, A. (2018). Peer learning in international higher education: The experience of international students in an Irish university. Irish Educational Studies, 38(1), 1-24. https://doi.org/10.1080/03323315.2018.1489299

Iorio, J., \& Pereira, S. (2018). Social class inequalities and international student mobility: The case of Brazilian students in the Portuguese higher education system. Belgeo, 3. https://doi.org/10.4000/belgeo.24193

Kabanbayeva, G., Gureva, M., Bielik, P., \& Ostasz, G. (2019). Academic mobility and financial stability: A case of Erasmus student exchange program. Journal of International Studies, 12(1), 324-337. http://doi.org/10.14254/2071-8330.2019/12-1/22

Kirkpatrick, D. L., \& Kirkpatrick, J. D. (2006). Evaluating training programs. San Francisco: Berrett-Koehler.

Knight, J. (2008). Higher education in turmoil. The changing world of internationalization. Rotterdam: Sense Publishers.

Knight, J. (2013). The changing landscape of higher education internationalisation - For better or worse? Perspectives: Policy and Practice in Higher Education, 17(3), 84-90. https://doi.org/10.1080/13603108.2012.753957

Kőmíves, P. M. (2014). Staff mobility as an aspect of the quality assurance in Hungarian universities. Procedia Social and Behavioral Sciences, 152, 1189-1193. https://doi.org/10.1016/j.sbspro.2014.09.297

Kompanets, V., \& Väätänen, J. (2018). Different, yet similar: Factors motivating international degree collaboration in higher education. The case of Finnish-Russian double degree programmes. European Journal of Engineering Education, 44(3), 379-397. https://doi.org/10.1080/03043797.2018.1520811

Ma, J., \& Wen, Q. (2018). Understanding international students' in-class learning experiences in Chinese higher education institutions. Higher Education Research \& Development, 37(6), 1186-1200. https://doi.org/10.1080/07294360.2018.1477740

McAleer, M., Nakamura, T., \& Watkins, C. (2019). Size, internationalization, and university rankings: Evaluating and predicting Times Higher Education (THE) data for Japan. Sustainability, 11(5), 1366. https://doi.org/10.3390/su11051366 
Miura, I. K. (2006). The internationalization process of the University of São Paulo: A study in three areas of knowledge. Thesis for Associate Position. Ribeirão Preto: University of São Paulo.

Nilemar, K., \& Brown, L. (2019). Academic mobility and cultural change. Journal of Further and Higher Education, 43(1), 1-12. https://doi.org/10.1080/0309877X.2017.1356914

Oliveira, A. L. D., \& Freitas, M. E. D. (2017). Intercultural relations in university life: Experiences of international mobility of teachers and students. Brazilian Journal of Education, 22(70), 774-801. https://doi.org/10.1590/s1413-24782017227039

Payumo, J. G., Lan, G., \& Arasu, P. (2017). Researcher mobility at a US research-intensive university: Implications for research and internationalization strategies. Research Evaluation, 27(1), 28-35. https://doi.org/10.1093/reseval/rvx038

Pegalajar Palomino, M. C., Pérez Navío, E., \& Colmenero Ruiz, M. J. (2014). Students' perceptions of the university system in the framework of the European Higher Education Area: Participation in international mobility programmes. Educatio Siglo XXI, 32(2). http://dx.doi.org/10.6018/j/202231

Pereira, Y. P., Souza, I. R., Rodrigues, A., \& Dias, C. (2017). Academic mobility: A comparative study in the context of university institutions. Magazine Gestão Universitária na América Latina - GUAL, 10(4), 252-268. https://doi.org/10.5007/1983-4535.2017v10n4p252

Perez-Encinas, A, Rodriguez-Pomeda, J. \& Josek, M. (2017). Problematic areas of host university support services for short-term mobility students. Journal of International Students, 7(4), 1030-1047. http://doi.org/10.5281/zenodo.1035959.

Petzold, K., \& Bucher, H. (2018). The academic mobility regime: Analysing perceptions of students and academic staff. International Review of Social Research, 8(1), 98-108. https://doi.org/10.2478/irsr-2018-0011

Popa, D., \& Knezevic, R. (2018). Academic mobility policies in higher education of Bosnia and Herzegovina. Revista de Pedagogie - Journal of Pedagogy, LXVI(1), 159-171. https://doi.org/10.26755/RevPed/2018.1/159

Ribeiro, M. F. (2014). Adaptation to new spaces: Erasmus students in Braga and Prague. Unpublished master's dissertation. Braga: University of Minho.

Rodríguez-Izquierdo, R. M. (2018). Intercultural sensitivity among university students: Measurement of the construct and its relationship with international mobility programmes. Culture and Education, 30(1), 177-204. https://doi.org/10.1080/11356405.2018.1435095

Tamkin, P, Yarnall, J., \& Kerrin, M. (2002). Kirkpatrick and Beyond: A review of models of training evaluation. Brighton-UK: Institute Employment Studies.

Tran, L. T., \& Vu, T. T. P. (2017). "Agency in mobility": Towards a conceptualisation of international student agency in transnational mobility. Educational Review, 70(2), 167-187. https://doi.org/10.1080/00131911.2017.1293615

Waters, J. L. (2018). International education is political! Exploring the politics of international student mobilities. Journal of International Students, 8(3), 1459-1478. http://doi.org/10.5281/zenodo.1254611

Weibl, G. (2015). Perceptions on the European Union's role in the internationalisation of higher education and support of international student mobility. Australian and New Zealand Journal of European Studies (ANZJES), $7(2), 58-75$.

Wekullo, C. S. (2019). International undergraduate student engagement: Implications for higher education administrators. Journal of International Students, 9(1), 320-337. https://doi.org/10.32674/jis.v9i1.257

Wilkins, E., \& Neri, S. (2018). Managing faculty in transnational higher education: Expatriate academics at international branch campuses. Journal of Studies in International Education, 23(4), 451-472. https://doi.org/10.1177/1028315318814200

Zahavi, H., \& Friedman, Y. (2019). The Bologna Process: An international higher education regime. European Journal of Higher Education, 9(1), 23-39. https://doi.org/10.1080/21568235.2018.1561314

Zhou, Y., Jindal-Snape, D., Topping, K., \& Todman, J. (2008). Theoretical models of culture shock and adaptation in international students in higher education. Studies in Higher Education, 33(1), 63-75. https://doi.org/10.1080/03075070701794833 